\section{JURNAL PARSPRINTH Junnal Kä|ian Sosidoci dan Pendidikkn}

Jurnal Perspektif: Jurnal Kajian Sosiologi dan Pendidikan Vol. 3 No. 1 Tahun 2020

http://perspektif.ppj.unp.ac.id

Email: perspektif@ppi.unp.ac.id

ISSN: 2622-1748 (Online), 2684-902X (Print)

DOI: http://dx.doi.org/10.24036/perspektif.v3i1.219

\title{
Pemanfaatan Utang Oleh Ibu-ibu Rumah Tangga Pada Rentenir di Jorong Kuranji Kecamatan Guguak VIII Koto Kabupaten Lima Puluh Kota
}

\author{
Chici Amedea1, Mira Hasti Hasmira ${ }^{2}$ \\ 1,2Universitas Negeri Padang \\ Email : chiciamedea27@gmail.com, mirahasti@fis.unp.ac.id
}

\begin{abstract}
Abstrak
Artikel ini ditulis berdasarkan penelitian yang telah dilakukan. Penelitian tersebut dilatarbelakangi oleh perilaku ketergantungan ibu-ibu rumah tangga terhadap rentenir di Jorong Kuranji Kecamatan Guguak VIII Koto. Adapun tujuan dari penelitian ini untuk mengetahui pemanfaatan utang oleh ibu-ibu rumah tangga pada rentenir di Jorong Kuranji Kecamatan Guguak VIII Koto. Teori yang digunakan yaitu teori pilihan rasional oleh James S Coleman. Metode penelitian yang digunakan adalah metode kualitatif dengan tipe studi kasus. Pemilihan informan dilakukan dengan teknik purposive sampling dengan total sebanyak 30 informan. Pengumpulan data dilakukan dengan metode observasi partisipasif, wawancara mendalam dan studi dokumentasi. Trianggulasi dilakukan untuk memeriksa keabsahan data yang menggunakan trianggulasi sumber. Teknik analisis data yang digunakan adalah teknik analisis data dari Milles dan Huberman (reduksi data, penyajian data dan penarikan kesimpulan). Berdasarkan pengumpulan data yang telah dilakukan diperoleh hasil terkait dengan pemanfaatan utang oleh ibu-ibu rumah tangga di Jorong Kuranji Kecamatan Guguak VIII Koto adalah (1) berdagang (2) Biaya Sekolah Anak (3) membeli barang yang tidak diperlukan.
\end{abstract}

Kata kunci: Ibu-ibu rumah tangga, Pemanfaatan, Rentenir, Utang

\section{Abstract}

This article is written based on research that has been done. The research was motivated by behavior of the dependence of housewives on loan sharks in Jorong Kuranji, Sub District of Guguak VIII Koto. The purpose of this research was to determine the use of debt by housewives in moneylender in Jorong Kuranji, Sub District of Guguak VIII Koto. This research used theory rational choice theory by James $S$ Coleman. The menthod used in this research is a qualitative menthod with type of case study. The selection of informants was cerried out using a purposive sampling technique with a total of 30 informants. Data collection was carried out using participatory observation methods, indepth interviews and documentation studies.Triangulationis carried out to check the validity of the data using source triangulation. Data analysis techniques used is the analysis technique of Milles and Huberman( data reduction, data presentation and drawing conclusions).Based on data collection results obtained relation to the use of debt by housewives in Jorong Kuranji, Sub district Guguak VIII Koto are (1) tranding (2) school fees for children (3) buying unnessary goods.

Keyword: Debt, Moneylenders, Housewives, Utilization,

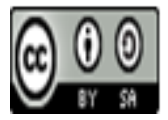


Chici Amedea, Mira Hasti Hasmira Pemanfaatan Utang oleh Ibu-ibu Rumah Tangga pada Rentenir di Jorong Kuranji Kecamatan Guguak VIII Koto Kabupaten Limo Puluh Koto

\section{Pendahuluan}

Kebutuhan masyarakat yang terus meningkat dan pendapatan rendah menyebabkan masyarakat memilih untuk memenuhi kebutuhannya denga cara berutang. Utang telah menjadi pilihan perilaku ekonomi masyarakat yang banyak digunakan untuk memenuhi kebutuhan hidup. Keinginan untuk berutang timbul karena adanya kebutuhan tertentu untuk menuntut adanya persediaan uang yang melebihi pendapatan. Kebutuhan tersebut dapat berupa kebutuhan yang sudah direncanakan atau kebutuhan yang mendesak secara tiba-tiba (Shohib, 2013). Utang merupakan salah satu kegiatan ekonomi antara manusia dengan manusia, manfaatnya antara lain yaitu tolong menolong dalam kehidupan sehari-hari yang bentuk transaksinya bisa dilakukan pada keseluruhan tingkatan masyarakat baik itu tradisional maupun modern (Yuswalinah, 2016).

Pada dasarnya semua orang pasti merasakan berutang baik itu pada keluarga, teman serta masyarakat dan pada lembaga keuangan. Hal ini karena kebutuhan hidup yang melebihi pendapatan yang ada menyebabkan masyarakat ketergantungan terhadap perilaku berutang. Semakin banyak masyarakat berutang, semakin merosot ekonomi masyarakat karena uang yang di dapatkan harus digunakan untuk membayar utang yang ada. Pinjaman (kontrak utang) adalah kontrak yang sederhana dengan sifat yang luar biasa dimana orang meminjamkan sesuatu dengan sifat yang luar biasa dimana orang meminjam sesuatu kepada orang lain dengan janji bahwa jika itu akan dilunasi dimasa depan dengan kompensasi bunga yang ditanggung peminjam (Herispon, 2017).

Berdasarkan penelitian tentang pemanfaatan utang oleh ibu-ibu rumah tangga pada rentenir di Jorong Kuranji Kecamatan Guguak VIII Koto Kabupaten Lima Puluh Kota bahwasannya masayarakatnya banyak meminjam uang baik itu pada lembaga keuangan resmi maupun lembaga keuangan tidak resmi yang biasanya disebut dengan" rentenir ". Renten atau kegiatan renten merupakan suatu aktifitas yang mana seseorang meminjam uang dengan bunga yang berlipat-lipat yang memungkinkan bunga tersebut melebihi utang pokoknya jika cicilannya terlambat (Siboro, 2015). Seperti pinjaman pada umumnya, pinjaman dengan rentenir melibatkan dengan dua belah pihak yaitu pihak yang memberi pinjaman (rentenir) dan pihak yang menerima pinjaman (debitor). Perjanjian pinjam meminjam uang disertai dengan bunga merupakan salah satu bentuk perjanjian yang telah lama lahir dalam masyarakat, sehingga membuat pengaruh yang begitu besar terhadap perekonomian (Arief \& Sutrisni, 2013).

Sebelum melakukan pinjaman, kedua belah pihak ini sudah melakukan perjanjian yang disepakati yang disertai dengan bunga yang sudah ditentukan oleh rentenir tersebut (Syarif, 2017). Rentenir menawarkan pinjaman tanpa memakai syarat yang tidak berbelit-belit tetapi dengan bunga yang cukup besar dengan kisaran 20\% sampai dengan 30\% dengan pembayaran 30 hari atau dalam jangka waktu 1 bulan tergantung nominal uang yang di pinjam dan dibayar satu kali sehari. Biasanya masyarakat meminjam uang dengan rentenir sebanyak Rp. 100.000,- sampai dengan Rp. 1.000.000,- sesuai dengan kebutuhan dengan pembayaran perhari Rp. 40.000,- Pelepas uang (rentenir) akan berusaha mendapatkan nasabah sebanyak-banyaknya. Semakin banyak nasabah dan uang yang dipinjamkan maka semakin banyak pula keuntungan yang diperoleh (Panajitan, 2018). Apabila tidak pandai menggunakan dengan yang ia pinjam dan bukan digunakan untuk kebutuhan produktif maka ia akan berdampak negatif dn berakibat perekonomian keluarga kurang baik karena harus berbagi penghasilan untuk kebutuhan keluarga dan membayar cicilan rentenir (Perlina, 2017).

Ibu-ibu rumah tangga di Jorong Kuranji lebih memilih berutang dengan rentenir karena lembaga keuangan resmi memiliki banyak persayaratan administrasi sehingga masyarakat 
tidak mau repot dalam mengurus surat-surat serta syarat lainnya yang menurut mereka rumit. Peminjaman pada lembaga keuangan resmi seperti bank nagari memiliki beberapa syarat peminjaman yaitu foto copy Kartu Tanda Penduduk (suami, istri), foto copy Kartu Keluarga, foto copy Surat Nikah, surat keterangan usaha dari Kantor Wali Nagari, foto copy agunan (Buku Pemilik Kendaraan Bermotor atau BPKB dan surat tanda nomor kendaraan/STNK, atau sertifikat), foto copy Nomor Pokok Wajib Pajak (NPWP), pas photo 4 x 6 dan 3 x 4 warna (suami,istri) dengan suku bunga sebesar 0,3\%.

Selain Bank Nagari juga ada koperasi yang dikelola oleh Badan Usaha Milik Pemerintah Daerah yaitu koperasi usaha ekomoni masyarakat simpan pinjam (UEM-SP SAIYO). Pada koperasi ini ada beberapa syarat yang harus dipenuhi oleh masyarakat yang ingin melakukan peminjaman yaitu dengan syarat harus menjadi anggota koperasi, simpanan pokok harus ada sebesar Rp. 200.000,- mengisi formulir pinjaman yang telah ditanda tanganin (suami, istri, mamak) bagi peminjam, suku bunga sebesar 5\% untuk peminjaman dan 5\% simwapin (simpan wajib pinjam), rentang waktu pembayaran 10 minggu, keterlambatan pembayaran akan didenda Rp. 5000,- per/pembayaran.

Dengan banyaknya syarat yang diajukan dalam peminjaman pada lembaga keuangan resmi menyebabkan masyarakat lebih memilih berhutang pada rentenir dari pada harus meminjam pada lembaga keuangan resmi yang syarat nya cukup rumit dan membutuhkan waktu lama. Peminjaman pada rentenir ini merupakan usaha pribadi yang tidak berbadan hukum yang memiliki manajemen sendiri yang dikelola oleh mayoritas sekelompok etnis batak dan juga ada etnis minang yang berasal dari jorong kuranji.

Berdasarkan penelitian, ditemukan 10 ibu-ibu rumah tangga yang berhutang pada rentenir, dengan latar belakang pendidikannya sebagian besar tamatan sekolah dasar. Ibu rumah tangga bukan hanya sebagai pengurus rumah tangga tetapi juga bberberan dalam membantu suami mencari nafkah. Ibu merupaka sosok sentral dalam sebuah keluarga (Hasmira, 2016). Pendapatan suami yang rendah membuat perempuan bertanggung jawab pula terhadap pemenuhan kebutuhan ekonomi keluarga. tetapi ibu-ibu rumah tangga juga berperan dalam memenuhi kebutuhan keluarga (Ebbi et al., 2019). Dalam hal tersebut ibu-ibu memenuhi kebutuhannya dengan cara berhutang pada rentenir untuk dijadikan modal usaha dan kebutuhan lainnya.

Penelitian yang relevan terkait rentenir telah banyak dilakukan diantaranya yang berfokus pada hubungan rentenir terhadap fungsi pinjaman berbunga, sistem utang piutang yang berjalan berdasarkan aturan-aturan yang tidak sama dengan aturan yang berlaku pada lembaga keuangan lainnya, adanya fenomena hutang dan rentenir yang terjadi pada komunitas nelayan di pesisir selatan, penyebab masyarakat melakukan pinjaman pada rentenir dikarenakan masyarakat mempunyai sikap yang tidak menyukai hal yang berteletele, adanya kepentingan masyarakat melakukan pinjaman dana dengan rentenir yaitu untuk mengatasi permasalahan ekonomi keluarga, (Siboro, 2015; Maghfiro. 2014; Syafrini, 2014).

Menunjukkan bahwa penelitian yang berjudul Rentenir (Analisis terhadap Fungsi Pinjaman Berbunga dalam Masyarakat Rokan Hilir Kecamatan Bagan Sinembah Desa Bagan Batu) berfokus pada hubungn rentenir terhadap fungsi pinjaman berbunga. Prilaku masyarakat Rokan Hilir yang meminjam uang dengan rentenir terhadap pinjaman berbunga (Siboro, 2015). Maghfiro (2014) yang berjudul sistem Hutang Piutang Pada Masyarakat Miskin Di Desa Pikatan Kecamatan Gending Kabupaten Probolinggo yang menunjukkan adanya sistem hutang piutang yang berjalan berdasarkan aturan-aturan yang tidak sama dengan aturan yang berlaku pada lembaga keuangan lainnya. Para rentenir yang berada di desa pikatan kecamatan gending kabupaten probolinggo membuat peraturan yang lebih lunak agar masyarakat tidak kesulitan untuk mengakses pinjaman dari mereka (Maghfiro, 2014) 
Chici Amedea, Mira Hasti Hasmira Pemanfaatan Utang oleh Ibu-ibu Rumah Tangga pada Rentenir di Jorong Kuranji Kecamatan Guguak VIII Koto Kabupaten Limo Puluh Koto

Syafrini tahun 2014 yang berjudul Nelayan Vs Rentenir, Studi Ketergantungan Nelayan Terhadap Rentenir Pada Masyarakat Pesisir mengindikasikan adanya fenomena hutang dan rentenir yang terjadi komunitas nelayan di pesisir selatan (Syafrini, 2014). Artkel ini menjelaskan tentang pemanfaatan utang oleh ibu-ibu rumah tangga pada rentenir di Jorong Kuranji Kecamatan Guguak VIII Koto, Kabupaten Lima Puluh Kota.

\section{Metode Penelitian}

Lokasi penelitian ini adalah di Jorong Kuranji yaitu bertempat di Kecamatan Guguak VIII Koto Kabupaten 50 Kota. Penelitian tentang pemanfaatan hutang oleh ibu-ibu rumah tangga pada rentenir di Jorong Kuranji Kecamatan Guguak VIII Koto dilakukan menggunakan pendekatan penelitian kualitatif. Penelitian kualitatif yaitu suatu pendekatan yang menjelaskan realitas sosial yang ingin di teliti secara mendalam dengan menggunakan data kualitatif berupa fakta dan kenyataan.

Tipe penelitian yang diajukan peneliti yaitu penelitian studi kasus. Dimana dalam penelitian tersebut metode penelitian studi kasus bertujuan untuk memahami suatu objek yang di teliti secara khusus dan menjelaskan bagaimana keberadaan serta mengapa kasus tersebut terjadi. Informan adalah orang yang memberikan informasi dan kondisi yang berkaitan dengan masalah penelitian. Teknik pemilihan informan pada penelitian ini menggunakan puposive sampling berarti peneliti yang menentukan siapa yang menjadi informan dalam penelitian sesuai dengan kriteria yang telah ditentukan dalam penelitian dengan total informan sebanyak 30 informan

Observasi merupakan suatu teknik pengumpulan data dengan melakukan pengamatan dan catatan secara sistematik terhadap suatu fenomena dan gejala yang ada dalam objek penelitian. Observasi dilakukan dengan mengumpulkan data dengan mengambil secara langsung data dari masyarakat yang menjadi objek yang akan diteliti (Ritzer, 2003). Wawancara adalah teknik pengumpulan data dengan mengajukan pertanyaan langsung kepada informan atau objek yang akan diteliti. Wawancara bertujuan untuk memperoleh keterangan, pendirian, pendapat serta lisan dari seseorang yang bicara langsung dengan orang tersebut. Dengan demikian wawancara berbeda dengan mengobrol, bercakap-cakap dan beramah-tamah (Suyanto, 2011). Wawancara yang dilakukan dalampenelitian ini yaitu wawancara mendalam. Wawancara mendalam merupakan teknik pengumpulan data yang didasarkan oleh percakapan secara intensif saat melakukan wawancara.Studi dokumentasi merupakan pelengkap dari penggunaan metode observasi dan wawancara dalam penelitian. Hasil penelitian dari observasi dan wawancara yang lebih dapat dipercaya jika didukung oleh studi dokumen (Sugiyono, 2012). Agar data yang diperoleh dalam penelitian akurat, valid dan sah maka dilakukan dengan teknik triangulasi data. Triangulasi adalah teknik pemerikasaan keabsahan data dengan memanfaatkan sesuatu yang berada diluar data tersebut data yang sama dikumpukan dari objek yang berbeda, hal ini bertujuan untuk pengecekan atau perbandingan terhadap data yang sudah diperoleh (Ghony M. Djunaidi \& Fauzan, 2016)

\section{Hasil dan Pembahasaan}

Pemanfaatan utang oleh ibu-ibu rumah tangga yang meminjam uang pada rentenir. Pemanfaatan utang yang digunakan oleh ibu-ibu rumah tangga sebagai berikut: 
Chici Amedea, Mira Hasti Hasmira Pemanfaatan Utang oleh Ibu-ibu Rumah Tangga pada Rentenir di Jorong Kuranji Kecamatan Guguak VIII Koto Kabupaten Limo Puluh Koto

\section{Berdagang}

Dalam pembahasan ini penulis menyampaikan bahwa ibu-ibu rumah tangga di Jorong Kuranji Kecamatan Guguak VIII Koto memanfaatkan pinjaman pada rentenir sebagai modal usaha. Sebagian besar ibu-ibu rumah tangga menggunakan pinjaman rentenir untuk berdagang seperti menjual gorengan, makanan anak-anak sekolah, menjual kerupuk jengkol dan membuka warung kopi. Ibu-ibu rumah tangga meminjam pada rentenir dengan alasan tidak tercukupinya kebutuhan sehingga lebih memilih berhutang. Uang tersebut dijadikan sebagai berdagang kecil-kecilan yang dijual setiap hari untuk mendapatkan pendapatan setiap harinya. Dari penghasilan berdangang tersebut ibu-ibu rumah tangga dapat mengembangkan usahanya dan uang yang dihasilkan untuk membayar kembali utang pada rentenir dan pemenuhan kebutuhan setiap harinya.

\section{Biaya sekolah anak}

Adapun manfaat lainnya yang digunakan ibu-ibu rumah tangga dalam meminjam uang pada rentenir yaitu sebagai biaya sekolah dan kuliah anaknya. Selain untuk memenuhi kebutuhan pokok, uang yang dipinjam pada rentenir juga ada kebutuhan lainnya yaitu biaya sekolah anak yang tinggi apalagi ada salah seorang ibu-ibu rumah tangga yang membiayai kuliah kedua anaknya. Untuk keperluan anak sekolah ibu-ibu rumah tangga terpaksa meminjam uang pada rentenir dengan jumlah yang cukup besar. Sebagian besar ibu-ibu rumah tangga meminjam pada rentenir karena tidak memiliki biaya dan kebutuhan sekolah anak secara tiba-tiba maka sebagian besar ibu-ibu rumah tangga tersebut memilih alternatif untuk meminjam pada rentenir walaupun ibu-ibu tersebut tau jika pinjaman pada rentenir tersebut berbunga besar.

\section{Membeli Barang Yang Tidak Perlukan}

Ibu-ibu rumah tangga meminjam uang kepada rentenir untuk memenuhi kebutuhannya, tetapi lain halnya di Jorong kuranji. Ibu-ibu rumah tangga meminjam pada rentenir dimanfaatkan oleh rentenir untuk mendapatkan keuntungan dengan memaksa anggota pinjaman yang meminjam uang kepada rentenir tersebut untuk membeli barang yang tidak dibutuhkan oleh ibu-ibu rumah tangga. Dalam hal ini bukan ibu-ibu rumah tangganya yang menginginkan untuk membeli barang tetapi adanya ancaman yang diberikan dari rentenir, ancaman tersebut berupa tidak boleh meminjam atau pinjaman akan dihentikan. Rentenir menawarkan pembelian barang seperti panci, tupperware, dan barang elektronik lainnya dengan bujuk rayu rentenir berupa pembayaran pertama dibayar oleh rentenir dengan dihitung yang sama dalam pinjaman biasanya. Disini rentenir memanggil ibu-ibu rumah tangga yang meminjam untuk berkumpul agar anggota pinjaman tersebut banyak membeli barang dan mendapatkan keuntungan yang besar.

Teori yang digunakan dalam artikel ini adalah teori pilihan rasional yang dikembangkan oleh James S Coleman, dalam teori tersebut menjelaskan bahwa adanya tindakan rasional yang dilakukan oleh individu atau aktor dalam memilih suatu pilihan. Dalam teori Coleman juga dijelaskan dua unsur utama dalam pilihan rasional yaitu aktor dan sumber daya. Aktor memiliki peran penting dalam melakukan suatu tindakan yang bertujuan untuk menentukan suatu nilai serta pilihan dalam memenuhi kebutuhannya. Sedangkan sumber daya merupakan suatu hal yang dianggap menarik oleh pihak lain yang dikontrol oleh aktor. Aktor dalam penulisan ini adalah ibu-ibu rumah tangga yang berhutang pada rentenir sedangkan sumber dayanya yaitu pinjaman yang diberikan oleh rentenir pada ibu-ibu rumah tangga. 
Berdasarkan artikel yang ditulis sesuai penelitian yang telah dilakukan bahwa ibu-ibu rumah tangga memilih untuk berhutang baik pada koperasi resmi maupun koperasi tidak resmi. Kedua pilihan tersebut memiliki dampak negatif dan dampak postif sesuai dengan pilihan ibu-ibu rumah tangga dalam memenuhi kebutuhannya. Dalam memenuhi kebutuhannya ibu-ibu rumah tangga memanfaatkan pinjaman rentenir untuk modal usaha seperti berdagang, biaya sekolah anak dan membeli barang yang tidak diperlukan. Penulis juga mengkaitkan hal tesebut dengan teori pilihan rasioanal dimana ibu-ibu memilih memanfaatkan uang pinjaman dengan baik atau tidak yang menurut mereka rasioanal dalam memakai uang seperti dalam berdagang. Berdagang merupakan pilihan yang rasioanal yang lebih diperlukan dalam pemenuhan kebutuhan keluarga sehingga hal tersebut mendapatkan hal yang positif dalam memenuhi kebutuhannya.

\section{Kesimpulan}

Kebutuhan masyarakat yang terus meningkat dan pendapatan rendah menyebabkan masyarakat memilih untuk memenuhi kebutuhannya dengan cara berutang. Utang telah menjadi pilihan prilaku ekonomi masyarakat yang banyak digunakan untuk memenuhi kebutuhan hidup. Berdasarkan artikel yang dibuat penulis dapat disimpulkan bahwa di Jorong Kuranji Kecamatan Guguak VIII Koto sebagian besar ibu-ibu rumah tangga menggunakan altelnatif untuk memenuhi kebutuhannya dengan cara meminjam uang pada rentenir. Pinjaman tersebut digunakan untuk kebutuhan yang direncanakan dan kebutuhan yang mendesak. Kebutuhan yang direncanakan seperti berdagang agar mendapatkan penghasilan setiap harinya untuk memenuhi kebutuhan yang diperlukan selanjutnya kebutuhan yang mendesak seperti biaya sekolah anak dimana ibu-ibu rumah tangga meminjam uang dengan alasan untuk biaya sekolah anak setiap harinya, selain itu ibu-ibu rumah tangga juga menggunakan uangnya untuk membeli barang yang tidak diperlukan karena adanya pengaruh dari rentenir.

\section{Daftar Pustaka}

Arief, M. Z., \& Sutrisni. (2013). Praktek Rentenir Penghambat Terwujudnhya Sistem Hukum Perbankan Syari'ah di Kabupaten Sumenep. Jurnal : Performance, III(63-82).

Ebbi, R., Artih, D., \& Susilawati, N. (2019). Dominasi Perempuan Sebagai Pencari Nafkah Utama dalam Keluarga Buruh Tani (Studi Kasus di Desa Batu Hampar Kecamatan Kayu Aro Barat Kabupaten Kerinci). Jurnal Perspektif: Jurnal Kajian Sosiologi Dan Pendidikan, 2(4), 449-455.

Ghony M. Djunaidi, \& Fauzan, A. (2016). Metodologi Penelitian Kualitatif. Jakarta: Ar-Ruzz Media.

Hasmira, M. H. (2016). Ibu-ibu Online: Antara Kuis Hunters (Kuters) dan Pelaksana Fungsi Dalam Keluarga. Socius, 3(1), 51-69.

Herispon. (2017). Utang Konsumtif Rumah Tangga dalam Perspektif Konvensional dan Syariah. Jurnal : Kajian Ekonomi Islam, 2(2), 141-152.

Maghfiro, W. (2014). Sistem Hutang Piutang pada Masyarakat Miskin di Desa Pikatan. Skripsi. Universitas Jember.

Panajitan, F. E. (2018). Praktis Pelepas uang /rentenir Di Nagari Lubuk Basung Kabupaten Agam Sumatera Barat. Jurnal Buana, 2(1), 398-409.

Perlina, Y. (2017). Praktik Pinjaman Rentenir dan Perkembangan Usaha Pedagang di Pasar Prapatan Panjalin Majalengka. Inklusif, 2(2), 100. https://doi.org/10.24235/ 
inklusif.v2i2.1938

Ritzer, G. (2003). Sosiologi Ilmu Pengetahuan Berparadigma Ganda. Jakarta: PT Raja Grafindo Persada.

Shohib, M. (2013). Sikap Terhadap Uang dan Perilaku Berhutang. Jurnal : Ilmiah Psikologi Terapan, 53(9), 1689-1699. https://doi.org/10.1017/CBO9781107415324.004

Siboro, I. K. (2015). Rentenir (Analisis Terhadap Fungsi Pinjaman Berbunga dalam Masyarakat Rokan Hilir Kecamatan Bagan Sinembah Desa Bagan Batu). JOM FISIP, 2(2), 1-15. http://garuda.ristekdikti.go.id/journal/article/295138

Sugiyono. (2012). Metode Penelitian Kuantitatif, Kualitatif dan R\&D. Yogyakarta: Alfabeta. Suyanto, B. (2011). Metode Penelitian Sosial. Bandung: Prenada Media Grup.

Syafrini, D. (2014). Nelayan vs Rentenir Studi Ketergantungan Nelayan terhadap Rentenir pada Masyarakat Pesisir. Jurnal Ilmu Sosial: Mamangan, 1(2), 54-67.

Syarif, A. A. (2017). Penyalahgunaan Keadaan dalam Perjanjian Pinjam Meminjam Uang oleh Rentenir. Renaissance, 2(2), 278-299. https://doi.org/10.20885/jlr.vol2.iss2.art2

Yuswalinah. (2016). Hutang-Piutang dalam Prespektif Fiqh Muamalah di Desa Ujung Tanjung Kecamatan Banyuasin III Kabupaten Banyuasin. Intizar, 19(2), 395-410. https://doi.org/10.19109/intizar.v19i2.419 